Review:

\title{
Optimal pig donor selection in islet xenotransplantation: current status and future perspectives*
}

\author{
Hai-tao ZHU ${ }^{\dagger}$, Liang YU, Yi LYU, Bo WANG ${ }^{\dagger *}$ \\ (Department of Hepatobiliary Surgery, the First Affiliated Hospital, Medical College, Xi'an Jiaotong University, Xi'an 710061, China) \\ †E-mail: zht0915@163.com; bobwang75@yeah.net \\ Received Apr. 28, 2014; Revision accepted July 21, 2014; Crosschecked July 25, 2014
}

\begin{abstract}
Islet transplantation is an attractive treatment of type 1 diabetes mellitus. Xenotransplantation, using the pig as a donor, offers the possibility of an unlimited supply of islet grafts. Published studies demonstrated that pig islets could function in diabetic primates for a long time ( $>6$ months). However, pig-islet xenotransplantation must overcome the selection of an optimal pig donor to obtain an adequate supply of islets with high-quality, to reduce xenoantigenicity of islet and prolong xenograft survival, and to translate experimental findings into clinical application. This review discusses the suitable pig donor for islet xenotransplantation in terms of pig age, strain, structure/function of islet, and genetically modified pig.
\end{abstract}

Key words: Islet, Pig, Xenotransplantation, Donor doi:10.1631/jzus.B1400120 Document code: A

\section{Introduction}

Pancreatic islet transplantation is emerging as a viable and prospective treatment option for patients with type 1 diabetes mellitus (T1DM), but shortage of donors (islet supply crisis) greatly restricts the development of clinical islet transplantation (Shapiro et al., 2000; van der Windt et al., 2012). The inability of human donor programs to meet present demands stimulates exploration of alternative sources of islet grafts. Xenotransplantation, using the pig as the source of islet cells, is a potential and promising solution to this dilemma (Cardona et al., 2007; Wang et al., 2011; Cooper et al., 2013; Lee et al., 2013; Hu et al., 2014). The pig is considered as the most suitable candidate for xenologous islet grafts owing to several advantages including (1) structural similarity of insulin between pig and human, just only one amino

\footnotetext{
${ }^{\ddagger}$ Corresponding author

* Project supported by the National Natural Science Foundation of China (No. 30700772)

(C) Zhejiang University and Springer-Verlag Berlin Heidelberg 2014
}

CLC number: R617; R335+ 6 acid difference; (2) availability in sufficient quantities (Gray et al., 2004; Yonekawa et al., 2005; Zhu et al., 2012); (3) feasibility in genetic immunomodulation (Klymiuk et al., 2012; Yeom et al., 2012; Nagaraju et al., 2013); (4) lack of amyloid formation (Potter et al., 2010); (5) resistance to recurrent autoimmunity (Koulmanda et al., 2003); and, (6) few ethical problems associated with slaughter pigs.

Nevertheless, initiation of clinical application of pig islets still requires additional progress to overcome several major hurdles: inadequate supply of islet cells with high-quality, xenorejection, and xenosis (Rood et al., 2006; Elliott, 2011; van der Windt et al., 2012; Hu et al., 2014). Donor pig age (islet type) contributes much to islet yield and functionality, as well as immunogenicity. Strain and breed of donor pigs are the important parameters influencing the outcome of islet isolation. The production of pathogen-free pigs can partially solve the problem of xenosis. In addition, xenogeneic rejection may be overcome by the current production of genetically modified pigs (Klymiuk et al., 2012; 
Yeom et al., 2012). Therefore, in order to form a basis for a breeding project and effectively push islet xenotransplantation into routine clinical practice, a suitable candidate pig must be determined and selected; and a summary of current knowledge about pig donor selection is necessary, which is the purpose of this review.

\section{Optimum age of donor pig}

A significant debate has taken place about whether the most optimal islet grafts for preclinical/ clinical xenotransplantation should be from embryonic, fetal, neonatal, young, or adult pigs (Dufrane and Gianello, 2008; van der Windt et al., 2012) (Table 1). At present, only islet xenografts isolated from neonatal (2-3 d) and adult pigs ( $>6$ months) display the ability to reverse diabetes in non-human primates (NHPs) or humans (Hering et al., 2006; Elliott et al., 2007; Dufrane et al., 2010; Thompson et al., 2012).

\subsection{Embryonic pig islet tissue}

Pig embryos can be easily obtained from pregnant sows at precisely-defined stages of their pregnancy. Embryonic pancreatic tissues are then extracted under a light microscope and maintained in culture medium at $4{ }^{\circ} \mathrm{C}$ pending transplantation
(Eventov-Friedman et al., 2006). Usually, only islet tissues harvested at embryonic gestational age $42 \mathrm{~d}$ (E42) are regarded as the best choice for xenotransplantation in diabetic rodents or monkeys (with immunosuppression) with several advantages including reduced immunogenicity, long-term proliferative potential, revascularization by host endothelium, and favorable endocrine/exocrine ratio (primarily composed of endocrine tissue with minimal exocrine activity) (Eventov-Friedman et al., 2006; Hecht et al., 2009; Tchorsh-Yutsis et al., 2009; 2011). However, the embryonic implants exhibit a delayed insulin response to glucose in vivo, and a period of $>3$ months of growth is required to effectively restore normoglycemia (Table 1) (Eventov-Friedman et al., 2006; Hecht et al., 2009; Tchorsh-Yutsis et al., 2009; 2011). In addition, further fine tuning of immunosuppressive strategy, tissue dose, risk of tumorigenesis, and implantation techniques are still to be addressed.

\subsection{Fetal pig islet}

Fetal pig islet-like cell clusters (ICCs) and neonatal pig islets (NPIs) are immature cells, which can be easily obtained by enzymatic digestion and simple pre-transplantation culture (4-9 d) on account of relative lack of exocrine tissues and concomitant relative abundance of endocrine tissues (Korbutt et al., 1996; Söderlund et al., 1999; Rajotte, 2008). In general,

Table 1 Benefits and drawbacks of islets isolated from donor pigs with different ages

\begin{tabular}{|c|c|c|}
\hline Donor pig age & Benefit & Drawback \\
\hline Embryonic & $\begin{array}{l}\text { Sterile procurement; } \\
\text { no isolation procedure; } \\
\text { proliferation and maturation in vivo; } \\
\text { relatively reduced immunogenicity; } \\
\text { low risk of pathogen transmission }\end{array}$ & $\begin{array}{l}\text { Delayed in vivo functionality ( }>3 \text { months); } \\
\text { tumorigenicity }\end{array}$ \\
\hline Fetal & $\begin{array}{l}\text { Sterile procurement; } \\
\text { easy islet isolation and no purification process; } \\
\text { resistance against ischemic injury; } \\
\text { proliferation in vivo; } \\
\text { low risk of pathogen transmission }\end{array}$ & $\begin{array}{l}\text { No response to glucose in vitro; } \\
\text { delayed in vivo functionality ( }>2 \text { months); } \\
\text { ethical problem (need for many donors) }\end{array}$ \\
\hline Neonatal & $\begin{array}{l}\text { Sterile procurement; } \\
\text { easy islet isolation and no purification process; } \\
\text { proliferation and differentiation in vivo; } \\
\text { resistance against ischemic injury; } \\
\text { more responsive to glucose vs. fetal }\end{array}$ & $\begin{array}{l}\text { Delayed in vivo functionality ( }>4 \text { weeks); } \\
\text { lower islet yields vs. adult }\end{array}$ \\
\hline Adult & $\begin{array}{l}\text { Consistent and high islet yields (possible one pig } \\
\text { required per patient); } \\
\text { direct islet function and diabetes correction }\end{array}$ & $\begin{array}{l}\text { Lack of sterile environment (slaughterhouse); } \\
\text { difficult isolation and purification process; } \\
\text { high costs }\end{array}$ \\
\hline
\end{tabular}


fetuses at $66-86 \mathrm{~d}$ of gestation are used for islet graft preparation since these ICCs possess better survival potential (Groth et al., 1994; Georges et al., 2002). Both ICCs and NPIs are also resistant to ischemic and inflammatory damages during the isolation process, which makes islet recovery more efficient. However, the main problem with ICCs is the need for long-term maturation (2-3 months) to achieve in vivo functionality (Hardikar et al., 2002). A second disadvantage is the relatively high expression of galactose- $\alpha-1,3-$ galactose (Gal) on the surface of ICCs, rendering wild-type (WT) pig ICCs more susceptible to xenorejection than adult pig islets (APIs), which express negligible amounts of Gal epitope (only 5\% of total cells) (Bennet et al., 2000; Rayat et al., 2003; Dor et al., 2004; Komoda et al., 2004). In non-diabetic cynomolgus monkeys, pig ICCs transplanted under kidney capsules were almost completely destroyed by immune rejection within $12 \mathrm{~d}$ post-transplantation (Söderlund et al., 1999). Although a previous study demonstrated that the transplanted pig ICCs could survive in the human body (Groth et al., 1994), up until now, the sustained long-term function of ICCs has not been documented in diabetic primates. Furthermore, an increasing improvement in achieving good outcomes in API isolation is stimulating a move away from ICCs in preclinical studies.

\subsection{Neonatal pig islet}

Generally, newborn pigs ( $1-5 \mathrm{~d}$ old) are selected for neonatal islet cell preparation. After in vitro culture (usually 4-9 d), tissue from one neonatal pancreas can yield about 50000 NPI aggregates, consisting of fully differentiated pancreatic endocrine cells (approximately 35\%) and endocrine precursor cells (approximately 57\%) (Korbutt et al., 1996; Rajotte, 2008; Dufrane and Gianello, 2009). NPIs are able to functionally correct hyperglycemia in diabetic recipients, which is mainly due to $\beta$ cell proliferation and/or striking differentiation of precursor cells into $\beta$ cells (Korbutt et al., 1996; Yoon et al., 1999; Trivedi et al., 2001; Nielsen et al., 2003). Though insulin secretion is also delayed after transplantation in vivo, the maturation time of NPIs ( $>4$ weeks) is significantly shorter than that of ICCs ( $>2$ months) (Table 1$)$ The origin of xeno-antigenicity of pig NPIs is mainly $N$-linked sugars including sialic acid and $\alpha$-Gal anti- gens (up to $11 \%-19 \%$ ) (Rayat et al., 2003; Omori et al., 2006); however, the transplanted NPIs induce a lower T-cell response than APIs in patients with insulin-dependent diabetes mellitus (Bloch et al., 1999). Recently, the growing demonstrations of prolonged diabetes reversal after transplantation of WT NPIs in immunosuppressed primates make neonatal pig an alternative source of islet grafts for future clinical application (Cardona et al., 2006; Elliott et al., 2007; Thompson et al., 2011a; Wang et al., 2011).

\subsection{Adult and young pig islets}

Adult pig is regarded as the primary donor source of islet xenografts, which can supply an adequate amount of viable islet cells and start functioning immediately after implantation (O'Neil et al., 2001; Dufrane et al., 2006). More than 200000 islet cells with high purity $(80 \%-95 \%)$ can be isolated from an adult pig donor (Ricordi et al., 1990; Inoue et al., 1992). Normally, insulin independence in diabetic NHPs can be achieved when a sufficient islet cell mass (25000-100000 islet equivalents (IEQ)/kg recipient body weight) is implanted (Hering et al., 2006; Casu et al., 2008; van der Windt et al., 2009; Thompson et al., 2011a; 2012), which requires pooling of islets from 2-4 adult pig donors or 7-10 neonatal pig donors (Korbutt, 2009). Generally, adult pigs aged $>2$ years (particularly retired breeders) are preferred as suitable donors, providing a greater number of islets with intact morphology, large size (150-200 $\mu \mathrm{m}$ ), and good structure (Dufrane et al., 2005a; 2005b; Bottino et al., 2007). Conversely, pancreata from neonatal or young pigs ( $<6$ months) are essentially composed of small islets with a diameter of 50-100 $\mu \mathrm{m}$ (Korbutt et al., 1996; Dufrane et al., 2005a). In large islets, the centralized structure for both collagen and capillaries can effectively reduce collagenase-induced injury and promote post-transplant revascularization. Although several studies reported poor insulin secretion or low islet recovery from isolated APIs in vitro (Nielsen et al., 2002; Yonekawa et al., 2005; Rijkelijkhuizen et al., 2006), the transplanted APIs still showed strong ability to restore normoglycemia in diabetic recipients in vivo (Nielsen et al., 2002; Yonekawa et al., 2005; Rijkelijkhuizen et al., 2006). Thus, APIs possess a better potential for functional engraftment and prolonged survival in islet xenotransplantation. 


\section{Selection of pig strain}

Pig islets are also considered more elusive on account of striking fragility, irregular shape, and quick dissociation into small aggregates or single cells during the isolation process (Bottino et al., 2007) Further, several studies have demonstrated great variability of islet capsule, size, and yield from various pig donors (Heiser et al., 1994; Kirchhof et al., 1994; Ulrichs et al., 1995; Meyer et al., 1997; Kim et al., 2007; Kinasiewicz et al., 2011). All these indicate that pig breed plays a vital role in islet quantity and function (Prabhakaran and Hering, 2008). Despite several years of investigation, no real consensus exists regarding the most optimal pig strain to provide the substantial amount of viable and functional islet grafts required for preclinical/clinical xenotransplantation.

\subsection{Pig strain selection based on peri-insular matrix}

An important aspect that may greatly influence islet quality and yield is the amount of extracellular matrix proteins (EMPs) surrounding the islet as a "capsule" which is subject to digestion by the enzyme collagenase (Stendahl et al., 2009). Therefore, the peri-insular matrix ("islet capsule") has a protective effect for the fragile islets. However, compared with humans and rats, the islet capsule in pigs is poorly developed, with very little peri-insular matrix present (van Deijnen et al., 1992). Moreover, only 25\% of all pig islets are encompassed by the collagen capsule, which covers $>75 \%$ of islet surfaces (Ulrichs et al., 1995). The major components of the islet capsule are collagen types I, III, IV, laminin, and fibronectin (Meyer et al., 1997). While disparity of expression of EMPs among individual pigs in the same strain is minimal, the disparity between different strains is considerable. In Hampshire (HA) and Duroc (DU) breeds, both the perimeter and thickness of islet capsule were significantly lower in comparison with other breeds (e.g., Landrace, Pietrain (PI) pigs) (Kirchhof et al., 1994). Among the tested breeds including DU, German Landrace (GL), Deutsches Edelschwein (DE), and hybrid pigs, the overall expression of EMPs appeared to be highest in GL breed and lowest in DU breed; furthermore, only the expression of collagen type I in GL breed was comparable to the human expression (Meyer et al., 1998).

Of importance, whether in minipig bred or market pigs, older individuals always seemed to display much more EMPs in the islet capsule than younger ones (Meyer et al., 1997; 1998). However, recent study showed that no significant differences between adult (12-78 months) and juvenile (6-12 months) pigs were detected in islet encapsulation (Hilling et al., 2010). Hence, the influence of other matrix elements and collagen subtypes should be further addressed in pig donor selection. In different pig strains, determination of EMP composition and expression level will greatly help to select and develop specific enzyme mixtures to improve islet integrity and yield.

\subsection{Pig strain selection based on islet morphology}

Morphological screening before isolation is necessary to select eligible donor pigs for acquiring a large number of islets with high-quality, reducing variance of isolation outcomes, and raising economic efficiency. Many studies indicated that a pancreas containing round-shape, well-demarcation, and largesize ( $>100 \mu \mathrm{m}$ diameter) islets could offer the greatest potential for successful isolation results (Mundwiler et al., 1994; Krickhahn et al., 2002; Gazda et al., 2005). Histomorphometry study conducted by Kirchhof et al. (1994) showed that GL and German Large White (GLW) pigs were more suitable islet donor breeds than DU, HA, PI, and WT pigs. The GL, GLW, and WT pigs displayed much greater islet numbers per area compared with DU and HA. However, the islet size in situ was smaller in WT boars than in all other breeds. Ulrichs et al. (1995) further demonstrated that the majority (59.8\%-68.9\%) of islets were $50-100 \mu \mathrm{m}$ in diameter in seven domestic races. Nevertheless, GL pigs revealed the greatest number (2\%) of large islets $(250-300 \mu \mathrm{m}$ and $>300 \mu \mathrm{m})$, and the greatest (up to $3.4 \%$ ) islet volume density (IVD; percent endocrine tissue of the total pancreas mass) of all pig breeds. By contrast, previous histological analysis of Kinasiewicz et al. (2011) suggested that PI pigs of $100 \mathrm{~kg}$ and market-weight pigs of $200 \mathrm{~kg}$ were preferable donors for islet grafts, which exhibited the largest value (range $1.20 \%-1.44 \%$ ) of IVD. In addition, the PI pigs showed a greater number of islets $/ \mathrm{cm}^{2}$ than Landrace pigs $\left((425.45 \pm 111.7)\right.$ islets $/ \mathrm{cm}^{2}$ vs. $(315.33 \pm$ $36.59)$ islets $\left./ \mathrm{cm}^{2}\right)$.

Kim et al. (2007) revealed that pancreata from adult Chicago Medical School (CMS) miniature 
(CM) pigs contained more islets with a diameter of $150-200 \mu \mathrm{m}(11.2 \%)$ than those from adult Prestige World Genetics (PWG) miniature (PM) pigs (2.4\%), and more islets with a diameter of $200-250 \mu \mathrm{m}(5.3 \%)$ than those from PM (1.6\%) or adult market pigs (1.3\%; from slaughterhouses); moreover, the mean IVD percentages of $\mathrm{CM}$ pigs were dramatically higher $(3.71 \%)$ than those of PM $(1.5 \%)$ or market pigs $(2.16 \%)$. Recently, Wuzhishan (WZS) miniature pigs were considered to be a feasible source of islet grafts with advantageous morphological features of denser islet capsule and larger splenic lobe of pancreas (Jiang et al., 2012). More importantly, the anatomical structure of the WZS miniature pig pancreas was more similar to human pancreas than that of market pigs.

\subsection{Pig strain selection based on islet yield}

Only few studies on pig islet isolation have directly addressed the influence of pig strain on islet yield. Islet yields (pre-purification) from marketweight $(100 \mathrm{~kg}$ ) purebred offspring of Landraces (two specific Landrace boars and Landrace sows) were much higher $((9350 \pm 630) \mathrm{IEQ} / \mathrm{g}$ and $(4800 \pm 760) \mathrm{IEQ} / \mathrm{g}$, respectively) than yields from hybrid offspring of the same boars and Yorkshire sows ((6150 \pm 780$) \mathrm{IEQ} / \mathrm{g}$ and (2990 \pm 520$) \mathrm{IEQ} / \mathrm{g}$, respectively) (Cavanagh et al., 1998). In the study by Ulrichs et al. (1995), GL pigs showed the highest numbers (22786 \pm 3739$)$ of theoretically calculated IEQ/g pancreas; however, only (687 \pm 515$) \mathrm{IEQ} / \mathrm{g}$ could be isolated (just $3.0 \%$ average yield), which was much lower than the yields of PI pigs ((2173 \pm 301$) \mathrm{IEQ} / \mathrm{g})$. Heiser et al. (1994) further confirmed that purebred PI pigs provided higher islet yields $((2180 \pm 317) \mathrm{IEQ} / \mathrm{g})$ than GL pigs $((606 \pm$ 379) IEQ/g), minipigs "Troll” ((691 \pm 357$) \mathrm{IEQ} / \mathrm{g})$, and adult hybrid pigs (mean $1190 \mathrm{IEQ} / \mathrm{g}$ ), and the improved islet viability was also observed. By contrast, Sabat et al. (2003) showed that islet yields in pancreata were less than $1000 \mathrm{IEQ} / \mathrm{g}$ from PI and Yokshire strains. The great variability of islet yield in the same breed is possibly related to variations in other factors including pancreas procurement, cold preservation, and isolation procedure/technique.

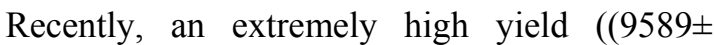
2823) IEQ/g) of well-functioning islets was obtained from CM pigs. Although the in vitro and in vivo functions of isolated islets showed no difference among experimental groups, the islet yields of adult CM pigs (>12 months) were significantly higher than those of adult PM pigs ((1752 \pm 874$)$ IEQ/g), adult market pigs ((1931 \pm 947$) \mathrm{IEQ} / \mathrm{g})$, or young (6-7 months) CM pigs $((3460 \pm 1985) \mathrm{IEQ} / \mathrm{g})$. Also, after digestion, islet yields in pancreata from adult inbred WZS miniature pigs (1-year-old, weighing $25-30 \mathrm{~kg}$ ) were much higher than the yields from market pigs $((6078 \pm$ $1105) \mathrm{IEQ} / \mathrm{g}$ vs. $(2500 \pm 625) \mathrm{IEQ} / \mathrm{g})$; moreover, the isolated islets from WZS pigs could efficiently respond to glucose challenge in vitro and in vivo (Jiang et al., 2012). In spite of reproductive history being a preferable donor parameter in miniature and market strain, male pigs usually provided higher islet yields compared with breeder miniature strain pigs (Kim $e t$ al., 2009).

In addition, in comparison with the marketraised breeds (e.g., Landrace) from slaughterhouses, the use of specific pathogen-free (SPF) miniature pigs as islet donors has additional advantages, including axenic and standardized pancreas procurement, short warm/cold ischemia time, and minimal possibility of zoonosis. Taken together, the use of the SPF miniature breed may permit great advances in the future preclinical/clinical application of pig islet xenotransplantation.

\section{Genetically engineered pig: an alternative selection of islet graft}

WT pig (e.g., DU, GLW, Landrace, and miniature) islet xenotransplantation has successfully reversed diabetes in primate models (Hering et al., 2006; Dufrane et al., 2010; Thompson et al., 2012). However, there is a significant loss of the transplanted cells on exposure to fresh recipient blood and heterologous antigen, known as instant blood-mediated inflammatory reaction (IBMIR), as well as subsequent humoral and T-cell response that results in xenorejection of islet grafts (Nilsson, 2008; Ekser and Cooper, 2010). The immunological rejection, which poses negative impacts on islet engraftment and survival, is still a major obstacle for clinical application of pig islet xenotransplantation.

Currently, the genetic engineering of pig seems to play a vital role in overcoming these problems, and the experience with transplantation of islets from 
these pigs into primates is steadily increasing (Table 2). The gene-modified pigs offer a number of potential advantages in reducing the IBMIR-related graft loss, protecting the islets from cellular rejection, minimizing the number of required islets, mitigating side effects of systemic immunosuppression, and improving islet activity and survival (Mandel et al., 1997; Komoda et al., 2005; Tai et al., 2007; D'Apice and Cowan, 2008; Thompson et al., 2011b; Nagaraju et al., 2013). Up to now, there are three main strategies to induce genetic modification in pigs, including knocking down/out genes responsible for major antigens targeted by natural anti-pig antibodies, knocking in human complement- and coagulationregulatory genes, as well as transferring T-cell co-stimulation blocking genes (Table 2). In diabetic primates, humoral rejection can be fully suppressed by crossbreeding of Gal gene-knockout (GTKO) pigs with transgenic pigs expressing human complement regulators such as CD46, CD59, and human decay-accelerating factor (hDAF, CD55) (Diamond et al., 2001; Liu et al., 2007; le Bas-Bernardet et al., 2011; Chen et al., 2014). In a humanized mouse model, islet grafts from cytotoxic $\mathrm{T}$ lymphocyte antigen 4-immunoglobulin (CTLA4Ig) transgenic pigs display the potential to normalize glucose homeostasis and inhibit cellular rejection (Klymiuk et al., 2012). Transgenic expression of human heme oxygenase-1
(HO-1) can protect pig islet cells from ischemia/ reperfusion injury, and/or acute rejection mediated by inflammatory cytokines (Yeom et al., 2012). Additional pig genetic modification, knocking-out tissue factor (TF) and over-expressing human antithrombotic gene (CD39/thrombomodulin), will certainly prevent the occurrence of IBMIR and coagulation dysfunction (Ekser and Cooper, 2010).

Given that genetically modified pig islets provide immunological benefits compared with those from WT, it is essential to determine the functionality of these mutations, particularly in regard to glucose metabolism and insulin secretion. As demonstrated by Casu et al. (2010), both WT (Landrace) and GTKO pigs had similar basal and stimulated blood glucose levels, as well as analogous reduction in blood glucose during the insulin tolerance test and intravenous glucose tolerance test. The study further demonstrated the good functionality of isolated GTKO islets in vitro, since stimulation indices of insulin secretion were similar and basal insulin secretion was higher than with WT islets. Furthermore, genetic engineering of the pigs (deletion of Gal epitope and/or the addition of human transgenes) also did not cause any abnormalities in hematologic, biochemical, or coagulation indicators, which might impact on animal welfare, and even possibly modified these parameters closer to human values (Ekser et al., 2012).

Table 2 Experience with genetically engineered pig islet xenotransplantation in diabetic primates

\begin{tabular}{|c|c|c|c|c|c|}
\hline Study & $\begin{array}{l}\text { Genetic engineering and } \\
\text { function feature }\end{array}$ & $\begin{array}{l}\text { Donor } \\
\text { age }\end{array}$ & $\begin{array}{l}\text { Diabetic } \\
\text { recipient }\end{array}$ & $\begin{array}{c}\text { Immunosuppressive } \\
\text { therapy }\end{array}$ & Islet xenograft survival \\
\hline $\begin{array}{c}\text { Mandel et al., } \\
1997\end{array}$ & $\begin{array}{l}\text { hDAF (CD55) transgenic pigs; } \\
\text { complement regulation }\end{array}$ & $\begin{array}{l}\text { Fetal (islet } \\
\text { tissues), } \\
70-90 \mathrm{~d}\end{array}$ & Cyno & $\begin{array}{c}\text { Group 1: none; } \\
\text { Group 2: } \\
\text { CsA+steroids }+\mathrm{CP} \text { or } \mathrm{BQR}\end{array}$ & $\begin{array}{l}\text { Group 1: } 3-7 \mathrm{~d} \\
\text { Group 2: }>40 \mathrm{~d}\end{array}$ \\
\hline $\begin{array}{l}\text { Komoda et al., } \\
2005\end{array}$ & $\begin{array}{l}\text { GnT-III transgenic pigs; } \\
\text { prevention of HAR }\end{array}$ & $\begin{array}{l}\text { Adult, } \\
>1 \text { year }\end{array}$ & $\begin{array}{l}\text { Cyno } \\
(n=4)\end{array}$ & None & $\begin{array}{c}1-5 \mathrm{~d} \\
((3.5 \pm 0.87) \mathrm{d})\end{array}$ \\
\hline $\begin{array}{l}\text { van der Windt } \\
\text { et al., } 2009\end{array}$ & $\begin{array}{l}\text { hCD46 transgenic pigs; } \\
\text { complement regulation }\end{array}$ & $\begin{array}{l}\text { Adult, } \\
2 \text { years }\end{array}$ & $\begin{array}{l}\text { Cyno } \\
(n=5)\end{array}$ & $\begin{array}{l}\text { MMF+ATG+ } \\
\text { anti-CD154 }\end{array}$ & $87-396 \mathrm{~d}$ \\
\hline $\begin{array}{l}\text { Thompson et al., } \\
\text { 2011b }\end{array}$ & $\begin{array}{l}\text { GTKO pigs; } \\
\text { resistance to complement/ } \\
\text { preformed xenoantibody } \\
\text { mediated injury }\end{array}$ & $\begin{array}{l}\text { Neonatal, } \\
1-4 \mathrm{~d}\end{array}$ & $\begin{array}{l}\text { Rhesus } \\
(n=5)\end{array}$ & $\begin{array}{l}\text { CTLA4Ig+anti-CD154+ } \\
\text { anti-LFA-1+MMF }\end{array}$ & $50-249 \mathrm{~d}$ \\
\hline $\begin{array}{l}\text { Chen et al., } \\
\quad 2014\end{array}$ & $\begin{array}{l}\mathrm{GTKO} / \mathrm{hCD} 55 / \mathrm{hCD} 59 / \mathrm{hHT} \\
\text { transgenic pigs; } \\
\text { combinations of genetic } \\
\text { modifications }\end{array}$ & Neonatal & $\begin{array}{l}\text { Baboon } \\
(n=3)\end{array}$ & $\begin{array}{l}\text { ATG }+ \text { MMF }+ \\
\text { tacrolimus }\end{array}$ & $\begin{array}{l}\text { Significant xenoantibody } \\
\text { response took place at } \\
28 \mathrm{~d} \text { after transplantation }\end{array}$ \\
\hline
\end{tabular}

hDAF (CD55): human decay-accelerating factor; GnT-III: $N$-acetylglucosaminyltransferase-III; HAR: hyperacute rejection; hCD46: human complement-regulatory protein; GTKO: Gal gene-knockout; hCD59: human CD59; hHT: human $\alpha(1,2)$ fucosyltransferase; Cyno: cynomolgus monkey; Rhesus: rhesus macaques; CsA: cyclosporine A; CP: cyclophosphamide; BQR: brequinar; MMF: mycophenolate mofetil; ATG: antithymocyte globulin; anti-CD154: anti-CD154 monoclonal antibody; CTLA4Ig: cytotoxic T lymphocyte antigen 4-immunoglobulin; anti-LFA-1: anti-lymphocyte function-associated antigen-1 monoclonal antibody 
Additionally, the risk of microbiological infection is still a possibility in xenotransplantation (Mueller et al., 2011). Most microorganisms can be eliminated by rearing the pig donors under qualified and SPF conditions. However, pig endogenous retrovirus (PERV) represents a special concern because it can be integrated into the pig genome (van der Laan et al., 2000; Patience et al., 2001; Denner, 2008). In clinical trials of pig islet xenotransplantation, although no evidence of PERV transmission was found in patients with T1DM after long-term follow-up (Valdes-Gonzalez et al., 2007; 2010; Wang et al., 2011), PERV infection remains a key issue. Previous study recommended domestic GL pig as the preferred islet source, since no evidence for PERV release (either as mRNA, or as protein or viral particles) was observed in the isolated islet cells (Irgang et al., 2008). In recent years, the development of RNA interference technology targeting PERV substantially mitigated the possible risk of retrovirus contamination; these transgenic pigs could maintain undetectable levels of PERV expression for a long term ( $>3$ years) (Ramsoondar et al., 2009; Semaan et al., 2012). With the emergence of other pathogens (e.g., pig lymphotropic herpesvirus, pig circovirus, and hepatitis E virus), gene-modified donor pigs will provide one of the best bases for solving bio-safety problems.

\section{Conclusions}

Considering that encouraging achievements in improving islet quality/quantity and extending islet survival have been obtained by pre-isolation donor selection, it is necessary to conduct more comprehensive metabolism, lineage, and genotyping analyses to form a basis for the selection or production of appropriate pig donors for fewer variable, lower microbiological, and more economical and effective islet preparation. In the future, for successful clinical practice, an adult pathogen-free transgenic pig with adequate islet yield, as well as functional insulin secretion and long-term islet survival, will be the most optimal donor for the large-scale clinical islet xenotransplantation.

\section{Compliance with ethics guidelines}

Hai-tao ZHU, Liang YU, Yi LYU, and Bo WANG declare that they have no conflict of interest.
This article does not contain any studies with human or animal subjects performed by any of the authors.

\section{References}

Bennet, W., Bjorkland, A., Sundberg, B., et al., 2000. A comparison of fetal and adult porcine islets with regard to Gal $\alpha(1,3) \mathrm{Gal}$ expression and the role of human immunoglobulins and complement in islet cell cytotoxicity. Transplantation, 69(8):1711-1717. [doi:10.1097/0000 7890-200004270-00030]

Bloch, K., Assa, S., Lazard, D., et al., 1999. Neonatal pig islets induce a lower T-cell response than adult pig islets in IDDM patients. Transplantation, 67(5):748-752. [doi:10. 1097/00007890-199903150-00018]

Bottino, R., Balamurugan, A.N., Smetanka, C., et al., 2007. Isolation outcome and functional characteristics of young and adult pig pancreatic islets for transplantation studies. Xenotransplantation, 14(1):74-82. [doi:10.1111/j.13993089.2006.00374.x]

Cardona, K., Korbutt, G.S., Milas, Z., et al., 2006. Long-term survival of neonatal porcine islets in nonhuman primates by targeting costimulation pathways. Nat. Med., 12(3): 304-306. [doi:10.1038/nm1375]

Cardona, K., Milas, Z., Strobert, E., et al., 2007. Engraftment of adult porcine islet xenografts in diabetic nonhuman primates through targeting of costimulation pathways. $\mathrm{Am}$. J. Transplant., 7(10):2260-2268. [doi:10.1111/j.16006143.2007.01933.x]

Casu, A., Bottino, R., Balamurugan, A.N., et al., 2008. Metabolic aspects of pig-to-monkey (Macaca fascicularis) islet transplantation: implications for translation into clinical practice. Diabetologia, 51(1):120-129. [doi:10. 1007/s00125-007-0844-4]

Casu, A., Echeverri, G.J., Bottino, R., et al., 2010. Insulin secretion and glucose metabolism in $\alpha 1,3$-galactosyltransferase knock-out pigs compared to wild-type pigs. Xenotransplantation, 17(2):131-139. [doi:10.1111/j.1399-3089. 2010.00572.x]

Cavanagh, T.J., Lakey, J.R., Wright, M.J., et al., 1998. Identification of a pig strain with maximal islet mass. Transplant. Proc., 30(2):368. [doi:10.1016/S0041-1345 (97)01312-2]

Chen, Y., Stewart, J.M., Gunthart, M., et al., 2014. Xenoantibody response to porcine islet cell transplantation using GTKO, CD55, CD59, and fucosyltransferase multiple transgenic donors. Xenotransplantation, 21(3):244-253. [doi:10.1111/xen.12091]

Cooper, D.K., Hara, H., Ezzelarab, M., et al., 2013. The potential of genetically-engineered pigs in providing an alternative source of organs and cells for transplantation. J. Biomed. Res., 27(4):249-253. [doi:10.7555/JBR.27. 20130063]

D'Apice, A.J., Cowan, P.J., 2008. Gene-modified pigs. Xenotransplantation, 15(2):87-90. [doi:10.1111/j.13993089.2008.00457.x]

Denner, J., 2008. Recombinant porcine endogenous retroviruses 
(PERV-A/C): a new risk for xenotransplantation? Arch. Virol., 153(8):1421-1426. [doi:10.1007/s00705-008-0141-7]

Diamond, L.E., Quinn, C.M., Martin, M.J., et al., 2001. A human CD46 transgenic pig model system for the study of discordant xenotransplantation. Transplantation, 71(1): 132-142. [doi:10.1097/00007890-200101150-00021]

Dor, F.J., Cheng, J., Alt, A., et al., 2004. Gala1,3Gal expression on porcine pancreatic islets, testis, spleen, and thymus. Xenotransplantation, 11(1):101-106. [doi:10. 1111/j.1399-3089.2004.00078.x]

Dufrane, D., Gianello, P., 2008. Pig islet xenotransplantation into non-human primate model. Transplantation, 86(6): 753-760. [doi:10.1097/TP.0b013e3181840f55]

Dufrane, D., Gianello, P., 2009. Pig islets for clinical islet xenotransplantation. Curr. Opin. Nephrol. Hypertens., 18(6):495-500. [doi:10.1097/MNH.0b013e328331a8e3]

Dufrane, D., Goebbels, R.M., Fdilat, I., et al., 2005a. Impact of porcine islet size on cellular structure and engraftment after transplantation: adult versus young pigs. Pancreas, 30(2):138-147. [doi:10.1097/01.mpa.0000147083.62501.4e]

Dufrane, D., Goebbels, R.M., Guiot, Y., et al., 2005b. Is the expression of Gal- $\alpha 1,3 \mathrm{Gal}$ on porcine pancreatic islets modified by isolation procedure? Transplant. Proc., 37(1): 455-457. [doi:10.1016/j.transproceed.2004.12.161]

Dufrane, D., D'hoore, W., Goebbels, R.M., et al., 2006. Parameters favouring successful adult pig islet isolations for xenotransplantation in pig-to-primate models. Xenotransplantation, 13(3):204-214. [doi:10.1111/j.1399-3089. 2006.00275.x]

Dufrane, D., Goebbels, R.M., Gianello, P., 2010. Alginate macroencapsulation of pig islets allows correction of streptozotocin-induced diabetes in primates up to 6 months without immunosuppression. Transplantation, 90(10):1054-1062. [doi:10.1097/TP.0b013e3181f6e267]

Ekser, B., Cooper, D.K., 2010. Overcoming the barriers to xenotransplantation: prospects for the future. Expert Rev. Clin. Immunol., 6(2):219-230. [doi:10.1586/eci.09.81]

Ekser, B., Bianchi, J., Ball, S., et al., 2012. Comparison of hematologic, biochemical, and coagulation parameters in a1,3-galactosyltransferase gene-knockout pigs, wild-type pigs, and four primate species. Xenotransplantation, 19(6):342-354. [doi:10.1111/xen.12007]

Elliott, R.B., 2011. Towards xenotransplantation of pig islets in the clinic. Curr. Opin. Organ Transplant., 16(2):195200. [doi:10.1097/MOT.0b013e3283449dec]

Elliott, R.B., Escobar, L., Tan, P.L., et al., 2007. Live encapsulated porcine islets from a type 1 diabetic patient $9.5 \mathrm{yr}$ after xenotransplantation. Xenotransplantation, 14(2): 157-161. [doi:10.1111/j.1399-3089.2007.00384.x]

Eventov-Friedman, S., Tchorsh, D., Katchman, H., et al., 2006. Embryonic pig pancreatic tissue transplantation for the treatment of diabetes. PLoS Med., 3(7):e215. [doi:10. 1371/journal.pmed.0030215]

Gazda, L.S., Adkins, H., Bailie, J.A., et al., 2005. The use of pancreas biopsy scoring provides reliable porcine islet yields while encapsulation permits the determination of microbiological safety. Cell Transplant., 14(7):427-439. [doi:10.3727/000000005783982846]

Georges, P., Muirhead, R.P., Williams, L., et al., 2002. Comparison of size, viability, and function of fetal pig islet-like cell clusters after digestion using collagenase or liberase. Cell Transplant., 11(6):539-545.

Gray, D.W., Sudhakaran, N., Titus, T.T., et al., 2004. Development of a novel digestion chamber for human and porcine islet isolation. Transplant. Proc., 36(4):11351138. [doi:10.1016/j.transproceed.2004.04.050]

Groth, C.G., Korsgren, O., Tibell, A., et al., 1994. Transplantation of porcine fetal pancreas to diabetic patients. Lancet, 344(8934):1402-1404. [doi:10.1016/S0140-6736 (94)90570-3]

Hardikar, A.A., Wang, X.Y., Williams, L.J., et al., 2002. Functional maturation of fetal porcine $\beta$-cells by glucagon-like peptide 1 and cholecystokinin. Endocrinology, 143(9):3505-3514. [doi:10.1210/en.2001-211344]

Hecht, G., Eventov-Friedman, S., Rosen, C., et al., 2009. Embryonic pig pancreatic tissue for the treatment of diabetes in a nonhuman primate model. PNAS, 106(21): 8659-8664. [doi:10.1073/pnas.0812253106]

Heiser, A., Ulrichs, K., Muller-Ruchholtz, W., 1994. Influence of porcine strain, age, and $\mathrm{pH}$ of the isolation medium on porcine pancreatic islet isolation success. Transplant. Proc., 26(2):618-620.

Hering, B.J., Wijkstrom, M., Graham, M.L., et al., 2006. Prolonged diabetes reversal after intraportal xenotransplantation of wild-type porcine islets in immunosuppressed nonhuman primates. Nat. Med., 12(3):301-303. [doi:10.1038/nm1369]

Hilling, D.E., Rijkelijkhuizen, J.K., Tons, H.A., et al., 2010. Porcine islet isolation outcome is not affected by the amount and distribution of collagen in the pancreas. Xenotransplantation, 17(3):250-255. [doi:10.1111/j.13993089.2010.00589.x]

Hu, Q., Liu, Z., Zhu, H., 2014. Pig islets for islet xenotransplantation: current status and future perspectives. Chin. Med. J. (Engl.), 127(2):370-377.

Inoue, K., Gu, Y., Shinohara, S., et al., 1992. Isolation of adult pig islet. In vitro assessment and xenotransplantation. Int. J. Pancreatol., 12(2):173-180.

Irgang, M., Laue, C., Velten, F., et al., 2008. No evidence for PERV release by islet cells from German landrace pigs. Ann. Transplant., 13(4):59-66.

Jiang, X., Qian, T., Linn, T., et al., 2012. Islet isolation and purification from inbred Wuzhishan miniature pigs. Xenotransplantation, 19(3):159-165. [doi:10.1111/j.13993089.2012.00702.x]

Kim, H.I., Lee, S.Y., Jin, S.M., et al., 2009. Parameters for successful pig islet isolation as determined using 68 specific-pathogen-free miniature pigs. Xenotransplantation, 16(1):11-18. [doi:10.1111/j.1399-3089.2008.00504.x]

Kim, J.H., Kim, H.I., Lee, K.W., et al., 2007. Influence of strain and age differences on the yields of porcine islet isolation: extremely high islet yields from SPF CMS 
miniature pigs. Xenotransplantation, 14(1):60-66. [doi:10. 1111/j.1399-3089.2006.00364.x]

Kinasiewicz, J., Antosiak-Iwanska, M., Sabat, M., 2011. Histomorphometrical analysis of porcine islets of Langerhans. Transplant. Proc., 43(8):3105-3106. [doi:10.1016/ j.transproceed.2011.08.022]

Kirchhof, N., Hering, B.J., Geiss, V., et al., 1994. Evidence for breed-dependent differences in porcine islets of Langerhans. Transplant. Proc., 26(2):616-617.

Klymiuk, N., van Buerck, L., Bahr, A., et al., 2012. Xenografted islet cell clusters from INSLEA29Y transgenic pigs rescue diabetes and prevent immune rejection in humanized mice. Diabetes, 61(6):1527-1532. [doi:10. 2337/db11-1325]

Komoda, H., Miyagawa, S., Kubo, T., et al., 2004. A study of the xenoantigenicity of adult pig islets cells. Xenotransplantation, 11(3):237-246. [doi:10.1111/j.1399-3089.2004. 00121.x]

Komoda, H., Miyagawa, S., Omori, T., et al., 2005. Survival of adult islet grafts from transgenic pigs with $\mathrm{N}$-acetylglucosaminyltransferase-III (GnT-III) in cynomolgus monkeys. Xenotransplantation, 12(3):209-216. [doi:10.1111/j.1399-3089.2005.00206.x]

Korbutt, G.S., 2009. The International Xenotransplantation Association consensus statement on conditions for undertaking clinical trials of porcine islet products in type 1 diabetes - Chapter 3: pig islet product manufacturing and release testing. Xenotransplantation, 16(4):223-228. [doi:10. 1111/j.1399-3089.2009.00542.x]

Korbutt, G.S., Elliott, J.F., Ao, Z., et al., 1996. Large scale isolation, growth, and function of porcine neonatal islet cells. J. Clin. Invest., 97(9):2119-2129. [doi:10.1172/ JCI118649]

Koulmanda, M., Qipo, A., Smith, R.N., et al., 2003. Pig islet xenografts are resistant to autoimmune destruction by non-obese diabetic recipients after anti-CD4 treatment. Xenotransplantation, 10(2):178-184. [doi:10.1034/j.13993089.2003.02040.x]

Krickhahn, M., Buhler, C., Meyer, T., et al., 2002. The morphology of islets within the porcine donor pancreas determines the isolation result: successful isolation of pancreatic islets can now be achieved from young market pigs. Cell Transplant., 11(8):827-838.

le Bas-Bernardet, S., Tillou, X., Poirier, N., et al., 2011. Xenotransplantation of galactosyl-transferase knockout, CD55, CD59, CD39, and fucosyl-transferase transgenic pig kidneys into baboons. Transplant. Proc., 43(9):3426-3430. [doi:10.1016/j.transproceed.2011.09.024]

Lee, J.I., Shin, J.S., Jung, W.Y., et al., 2013. Porcine islet adaptation to metabolic need of monkeys in pig-tomonkey intraportal islet xenotransplantation. Transplant. Proc., 45(5):1866-1868. [doi:10.1016/j.transproceed.2013. 01.090]

Liu, D., Kobayashi, T., Onishi, A., et al., 2007. Relation between human decay-accelerating factor (hDAF) expression in pig cells and inhibition of human serum anti-pig cytotoxicity: value of highly expressed hDAF for xenotransplantation. Xenotransplantation, 14(1):67-73. [doi:10. 1111/j.1399-3089.2006.00365.x]

Mandel, T.E., Koulmanda, M., Cozzi, E., et al., 1997. Transplantation of normal and DAF-transgenic fetal pig pancreas into cynomolgus monkeys. Transplant. Proc., 29(1-2): 940. [doi:10.1016/S0041-1345(96)00261-8]

Meyer, T., Czub, S., Chodnewska, I., et al., 1997. Expression pattern of extracellular matrix proteins in the pancreas of various domestic pig breeds, the Goettingen Minipig and the Wild Boar. Ann. Transplant., 2(3):17-26.

Meyer, T., Buhler, C., Czub, S., et al., 1998. Selection of donor pigs for pancreatic islet transplantation may depend on the expression level of connective tissue proteins in the islet capsule. Transplant. Proc., 30(5):2471-2473. [doi:10. 1016/S0041-1345(98)00692-7]

Mueller, N.J., Takeuchi, Y., Mattiuzzo, G., et al., 2011. Microbial safety in xenotransplantation. Curr. Opin. Organ Transplant., 16(2):201-206. [doi:10.1097/MOT. 0b013e32834486f6]

Mundwiler, K.E., Lamberti, F.V., Hill, R.S., 1994. Rapid and inexpensive method for the quantitative assessment of donor pancreata for islet isolation. Transplant. Proc., 26(6):3427.

Nagaraju, S., Bottino, R., Wijkstrom, M., et al., 2013. Islet xenotransplantation from genetically engineered pigs. Curr. Opin. Organ Transplant., 18(6):695-702. [doi:10. 1097/MOT.0000000000000020]

Nielsen, T.B., Yderstraede, K.B., Beck-Nielsen, H., 2002. Isolation, transplantation, and functional studies of adult porcine islets of Langerhans. Comp. Med., 52(2):127-135.

Nielsen, T.B., Yderstraede, K.B., Schroder, H.D., et al., 2003. Functional and immunohistochemical evaluation of porcine neonatal islet-like cell clusters. Cell Transplant., 12(1):13-25. [doi:10.3727/000000003783985142]

Nilsson, B., 2008. The instant blood-mediated inflammatory reaction in xenogeneic islet transplantation. Xenotransplantation, 15(2):96-98. [doi:10.1111/j.1399-3089.2008. 00460.x]

O'Neil, J.J., Stegemann, J.P., Nicholson, D.T., et al., 2001. The isolation and function of porcine islets from market weight pigs. Cell Transplant., 10(3):235-246.

Omori, T., Nishida, T., Komoda, H., et al., 2006. A study of the xenoantigenicity of neonatal porcine islet-like cell clusters (NPCC) and the efficiency of adenovirusmediated DAF (CD55) expression. Xenotransplantation, 13(5):455-464. [doi:10.1111/j.1399-3089.2006.00335.x]

Patience, C., Switzer, W.M., Takeuchi, Y., et al., 2001. Multiple groups of novel retroviral genomes in pigs and related species. J. Virol., 75(6):2771-2775. [doi:10.1128/JVI.75. 6.2771-2775.2001]

Potter, K.J., Abedini, A., Marek, P., et al., 2010. Islet amyloid deposition limits the viability of human islet grafts but not porcine islet grafts. PNAS, 107(9):4305-4310. [doi:10. 1073/pnas.0909024107]

Prabhakaran, S., Hering, B.J., 2008. What strain of pig should 
be used? Xenotransplantation, 15(2):83-86. [doi:10.1111/ j.1399-3089.2008.00456.x]

Rajotte, R.V., 2008. Isolation and assessment of islet quality. Xenotransplantation, 15(2):93-95. [doi:10.1111/j.13993089.2008.00459.x]

Ramsoondar, J., Vaught, T., Ball, S., et al., 2009. Production of transgenic pigs that express porcine endogenous retrovirus small interfering RNAs. Xenotransplantation, 16(3): 164-180. [doi:10.1111/j.1399-3089.2009.00525.x]

Rayat, G.R., Rajotte, R.V., Hering, B.J., et al., 2003. In vitro and in vivo expression of Gal $\alpha-(1,3) \mathrm{Gal}$ on porcine islet cells is age dependent. J. Endocrinol., 177(1):127-135. [doi:10.1677/joe.0.1770127]

Ricordi, C., Socci, C., Davalli, A.M., et al., 1990. Isolation of the elusive pig islet. Surgery, 107(6):688-694.

Rijkelijkhuizen, J.K., van der Burg, M.P., Tons, A., et al., 2006. Pretransplant culture selects for high-quality porcine islets. Pancreas, 32(4):403-407. [doi:10.1097/01.mpa. 0000220866.87658.b2]

Rood, P.P., Buhler, L.H., Bottino, R., et al., 2006. Pig-tononhuman primate islet xenotransplantation: a review of current problems. Cell Transplant., 15(2):89-104. [doi:10. 3727/000000006783982052]

Sabat, M., Godlewska, E., Kinasiewicz, J., et al., 2003. Assessment of some porcine strains as donors of islets of Langerhans. Transplant. Proc., 35(6):2343-2344. [doi:10. 1016/S0041-1345(03)00793-0]

Semaan, M., Kaulitz, D., Petersen, B., et al., 2012. Long-term effects of PERV-specific RNA interference in transgenic pigs. Xenotransplantation, 19(2):112-121. [doi:10.1111/ j.1399-3089.2012.00683.x]

Shapiro, A.M., Lakey, J.R., Ryan, E.A., et al., 2000. Islet transplantation in seven patients with type 1 diabetes mellitus using a glucocorticoid-free immunosuppressive regimen. N. Engl. J. Med., 343(4):230-238. [doi:10. 1056/NEJM200007273430401]

Söderlund, J., Wennberg, L., Castaños-Velez, E., et al., 1999. Fetal porcine islet-like cell clusters transplanted to cynomolgus monkeys: an immunohistochemical study. Transplantation, 67(6):784-791. [doi:10.1097/00007890199903270-00002]

Stendahl, J.C., Kaufman, D.B., Stupp, S.I., 2009. Extracellular matrix in pancreatic islets: relevance to scaffold design and transplantation. Cell Transplant., 18(1):1-12. [doi:10. 3727/096368909788237195]

Tai, H.C., Ezzelarab, M., Hara, H., et al., 2007. Progress in xenotransplantation following the introduction of geneknockout technology. Transpl. Int., 20(2):107-117. [doi:10.1111/j.1432-2277.2006.00398.x]

Tchorsh-Yutsis, D., Hecht, G., Aronovich, A., et al., 2009. Pig embryonic pancreatic tissue as a source for transplantation in diabetes: transient treatment with anti-LFA1, antiCD48, and FTY720 enables long-term graft maintenance in mice with only mild ongoing immunosuppression. Diabetes, 58(7):1585-1594. [doi:10.2337/db09-0112]

Tchorsh-Yutsis, D., Zlotnikov Klionsky, Y., Bachar-Lustig, E., et al., 2011. Embryonic pig pancreatic tissue for the treatment of diabetes: potential role of immune suppression with "off-the-shelf" third-party regulatory $\mathrm{T}$ cells. Transplantation, 91(4):398-405. [doi:10.1097/TP.0b013e 318204be15]

Thompson, P., Cardona, K., Russell, M., et al., 2011a. CD40-specific costimulation blockade enhances neonatal porcine islet survival in nonhuman primates. Am. J. Transplant., 11(5):947-957. [doi:10.1111/j.1600-6143. 2011.03509.x]

Thompson, P., Badell, I.R., Lowe, M., et al., 2011b. Islet xenotransplantation using gal-deficient neonatal donors improves engraftment and function. Am. J. Transplant., 11(12):2593-2602. [doi:10.1111/j.1600-6143.2011.03720.x]

Thompson, P., Badell, I.R., Lowe, M., et al., 2012. Alternative immunomodulatory strategies for xenotransplantation: CD40/154 pathway-sparing regimens promote xenograft survival. Am. J. Transplant., 12(7):1765-1775. [doi:10. 1111/j.1600-6143.2012.04031.x]

Trivedi, N., Hollister-Lock, J., Lopez-Avalos, M.D., et al., 2001. Increase in $\beta$-cell mass in transplanted porcine neonatal pancreatic cell clusters is due to proliferation of $\beta$-cells and differentiation of duct cells. Endocrinology, 142(5):2115-2122. [doi:10.1210/endo.142.5.8162]

Ulrichs, K., Bosss, M., Heiser, A., et al., 1995. Histomorphological characteristics of the porcine pancreas as a basis for the isolation of islets of Langerhans. Xenotransplantation, 2(3):176-187. [doi:10.1111/j.1399-3089.1995.tb0 0091.x]

Valdes-Gonzalez, R.A., White, D.J., Dorantes, L.M., et al., 2007. Three-yr follow-up of a type 1 diabetes mellitus patient with an islet xenotransplant. Clin. Transplant., 21(3):352-357. [doi:10.1111/j.1399-0012.2007.00648.x]

Valdes-Gonzalez, R., Dorantes, L.M., Bracho-Blanchet, E., et al., 2010. No evidence of porcine endogenous retrovirus in patients with type 1 diabetes after long-term porcine islet xenotransplantation. J. Med. Virol., 82(2):331-334. [doi:10.1002/jmv.21655]

van Deijnen, J.H., Hulstaert, C.E., Wolters, G.H., et al., 1992. Significance of the peri-insular extracellular matrix for islet isolation from the pancreas of rat, dog, pig, and man. Cell Tissue Res., 267(1):139-146. [doi:10.1007/BF00 318700]

van der Laan, L.J., Lockey, C., Griffeth, B.C., et al., 2000. Infection by porcine endogenous retrovirus after islet xenotransplantation in SCID mice. Nature, 407(6800): 90-94. [doi:10.1038/35024089]

van der Windt, D.J., Bottino, R., Casu, A., et al., 2009. Longterm controlled normoglycemia in diabetic non-human primates after transplantation with hCD46 transgenic porcine islets. Am. J. Transplant., 9(12):2716-2726. [doi:10.1111/j.1600-6143.2009.02850.x]

van der Windt, D.J., Bottino, R., Kumar, G., et al., 2012. Clinical islet xenotransplantation: how close are we? Diabetes, 61(12):3046-3055. [doi:10.2337/db12-0033]

Wang, W., Mo, Z., Ye, B., et al., 2011. A clinical trial of 
xenotransplantation of neonatal pig islets for diabetic patients. J. Central South Univ. (Med. Sci.), 36(12): 1134-1140. [doi:10.3969/j.issn.1672-7347.2011.12.002]

Yeom, H.J., Koo, O.J., Yang, J., et al., 2012. Generation and characterization of human heme oxygenase-1 transgenic pigs. PLoS ONE, 7(10):e46646. [doi:10.1371/journal. pone.0046646]

Yonekawa, Y., Matsumoto, S., Okitsu, T., et al., 2005. Effective islet isolation method with extremely high islet yields from adult pigs. Cell Transplant., 14(10):757-762. [doi:10.3727/000000005783982512]

Yoon, K.H., Quickel, R.R., Tatarkiewicz, K., et al., 1999. Differentiation and expansion of $\beta$ cell mass in porcine neonatal pancreatic cell clusters transplanted into nude mice. Cell Transplant., 8(6):673-689.

Zhu, H., Yu, L., Wang, B., 2012. Progress in isolation and purification of porcine islets. Chin. J. Reparat. Reconstr. Surg., 26(8):1012-1016 (in Chinese).

\section{中文㔍要:}

\section{本文题目：异种胰岛移植中供体猪的篮选：现状与进展}

Optimal pig donor selection in islet xenotransplantation: current status and future perspectives

本文概要: 猪胰岛细胞异种移植是一种极具潜力治疗糖尿病的方法。其临床应用主要面临两大挑战: 高 质量的活性胰岛短缺与异种免疫排斥反应。合适的猪供体篮选（年龄、性别、品系、基因表 型）是获取充足的高性能胰岛移植物的重要前提，并可有效地减轻胰岛异种抗原性及体内异 种排斥反应，进而延长移植物的功能存活时间。在文中，我们总结了异种移植中猪胰岛的相 关研究进展, 为供体猪的篮选提供了依据; 同时表明了无特殊病原体的成年转基因猪可能是 目前最佳的异种胰岛供体，有望在未来的临床研究中大规模应用。

关键词组: 胰岛; 猪; 异种移植; 供体 